\title{
TO THE NEW WORLD AND BACK AGAIN: RETURN MIGRANTS IN THE AGE OF MASS MIGRATION
}

\author{
Ran Abramitzky \\ Leah Platt Boustan \\ Katherine Eriksson \\ Working Paper 22659 \\ http://www.nber.org/papers/w22659 \\ NATIONAL BUREAU OF ECONOMIC RESEARCH \\ 1050 Massachusetts Avenue \\ Cambridge, MA 02138 \\ September 2016
}

We thank Orley Ashenfelter and Alex Mas for the invitation to present this paper at Henry Farber's Festschrift at Princeton University in April 2016. We appreciate helpful comments from Dylan Connor, Dora Costa, Walker Hanlon, Santiago Perez, Tom Zohar, and numerous participants at the Festschrift conference (not least of which, Hank himself!). The views expressed herein are those of the authors and do not necessarily reflect the views of the National Bureau of Economic Research.

NBER working papers are circulated for discussion and comment purposes. They have not been peer-reviewed or been subject to the review by the NBER Board of Directors that accompanies official NBER publications.

(C) 2016 by Ran Abramitzky, Leah Platt Boustan, and Katherine Eriksson. All rights reserved. Short sections of text, not to exceed two paragraphs, may be quoted without explicit permission provided that full credit, including $(\odot$ notice, is given to the source. 
To the New World and Back Again: Return Migrants in the Age of Mass Migration

Ran Abramitzky, Leah Platt Boustan, and Katherine Eriksson

NBER Working Paper No. 22659

September 2016

JEL No. J61,N31

\begin{abstract}
$\underline{\text { ABSTRACT }}$
We compile large datasets from Norwegian and US historical censuses to study return migration during the Age of Mass Migration (1850-1913). Return migrants were somewhat negatively selected from the migrant pool: Norwegian immigrants who returned to Norway held slightly lower-paid occupations than Norwegian immigrants who stayed in the US, both before and after moving to the US. Upon returning to Norway, return migrants held higher-paid occupations than Norwegians who never moved, despite hailing from poorer backgrounds. They were also more likely to get married after return. These patterns suggest that despite being negatively selected, return migrants were able to accumulate savings and improve their economic circumstances once they returned home.

Ran Abramitzky

Department of Economics

Stanford University

579 Serra Mall

Stanford, CA 94305

and NBER

ranabr@stanford.edu

Leah Platt Boustan

Department of Economics

8283 Bunche Hall

UCLA

Los Angeles, CA 90095-1477

and NBER

lboustan@econ.ucla.edu

Katherine Eriksson

Department of Economics

University of California, Davis

One Shields Avenue

Davis, CA 95616

and NBER

kaeriksson@ucdavis.edu
\end{abstract}




\section{Introduction}

30 million migrants moved from Europe to the United States during the Age of Mass Migration (1850-1913). Yet one in three of these arrivals eventually returned to Europe, a rate of return migration that is even higher than today (Gould 1980; Bandiera, Rasul and Viarengo, 2013; Dustmann and Gorlach, 2016). In this paper, we ask: who chose to move back from the US to Europe, and how did return migrants fare upon returning home? To the best of our knowledge, this paper provides the first analysis of return migrants to Europe in the late nineteenth and early twentieth century based on micro data.

Our analysis is based on the case of Norway. We compile two large panel datasets of return migrants to Norway observed at three points in their migration process: before they moved from Norway, either as children or as young adults; during their sojourn to the US; and after returning to Norway. For comparison, we also create a sample of more "permanent” migrants who we observe before and after migration to the US, and a sample of non-migrants who remained in Norway throughout the period. ${ }^{1}$ To do so, we exploit a special supplement of the 1910 Norwegian Census that asked the full population if they had ever lived in the United States. We link Norwegian-born men who lived either in Norway or in the US in 1910 to earlier Norwegian Censuses, where we measure pre-migration characteristics.

We find that migrants who returned to Norway held slightly lower-skilled occupations than did Norwegian migrants who stayed in the US permanently. This small but significant occupational gap was present both while abroad and before moving to the US. That return migrants were negatively selected from the migrant pool even before moving to the US is

\footnotetext{
${ }^{1}$ Some men that we classify here as permanent migrants may have eventually returned to the home country. We focus on men who had been in the US for at least five years to minimize this concern, given that more than half of temporary moves to the US lasted five years or less.
} 
contrary to the idea that return migration mostly resulted from bad shocks that prevented economic advancement in the destination.

Furthermore, the negative selection of return migrants in this context is not consistent with a simple Roy model. Unlike today, the occupation-based income distribution was more unequal in Norway than in the US (Abramitzky, Boustan and Eriksson, 2012). In such a setting, the Roy model predicts that higher skilled immigrants would be more likely to return to their home country (Borjas and Bratsberg, 1996; Dustman and Gorlach, 2016). The pattern of negative selection is more consistent with the possibility that low-skilled men who may have faced borrowing constraints at home used temporary migration as a means to buy land or make other local investments. ${ }^{2}$ Indeed, we find that immigrants who hailed from rural areas in Norway were more likely to return, and that these return migrants were likely to settle in their municipality of birth and work as owner-occupier farmers.

After going back to Norway, return migrants held higher-paid occupations than nonimmigrants, despite hailing from poorer backgrounds. Return migrants who stayed in the US for a short period (1-5 years) enjoyed the highest earnings premium in Norway. One interpretation for this finding is that successful migrants were able to accumulate savings and return home more quickly. ${ }^{3}$ Savings accumulated abroad may have also facilitated the investments necessary to start a new household before marriage. Before leaving for the US, return migrants were less likely than non-movers to be married, a pattern that reverses after return.

\footnotetext{
${ }^{2}$ On the use of temporary migration to accumulate savings, see Mesnard (2004), Yang (2006) and Wyman (1993).

3 Another interpretation, which is possible but seems less plausible, is that those returning relatively quickly might be "target savers," whereas those returning later might be "unplanned" returners who got bad shock in the US and decided to go back.
} 
Our paper contributes to a growing empirical literature exploring the economics of return migration. In the modern data, comparisons between return and permanent migrants are usually based on outcomes in the destination country, with the act of return migration inferred indirectly from attrition from a panel sample (Aydemir and Robinson, 2008; Bijwaard, Schluter and Wahba, 2014). ${ }^{4}$ In earlier work, we used a similar approach to generate indirect evidence on the selection of return migrants in historical data (Abramitzky, Boustan and Eriksson, 2012, 2014). ${ }^{5}$ Using these methods, we found evidence of mild negative selection of return migrants to Europe.

Our new historical dataset offers three advancements relative to the existing studies. First, our data contains a direct measure of return migration, which allows us to validate indirect evidence on the negative selection of return migrants to Europe. Second, the linked data allow us to observe pre-migration characteristics in the sending country. With information on premigration characteristics, we can separate explanations for negative selection based on either initial selection or on differential shocks in the destination country. Third, we estimate the economic return to time spent in the US using a set of Census questions asked of all residents of Norway in 1910, whereas modern studies rely on small source country surveys with retrospective migration histories (Wahba and Zenou, 2012; Reinhold and Thom, 2013).

\footnotetext{
${ }^{4}$ Rooth and Saarela (2007) is one exception. Linked register data allow the authors to observe pre-migration characteristics of return migrants from Sweden to Finland.

${ }^{5}$ Abramitzky, Boustan and Eriksson (2012, 2013) match Norwegian migrants living in the US in 1880 to either the US or Norwegian Census of 1900. Return migrants observed in Norway in 1900 were 3 percentage points more likely to have been in the lower quartile of the occupational distribution in 1880. Abramitzky, Boustan and Eriksson (2014) creates a panel dataset of migrants from 16 sending countries that were present in the 1900, 1910 and 1920 US Census; migrants in the panel are known not to return to Europe. We compare the panel data to a Census cross-section, which contains a weighted average of migrants who will eventually stay in the US and those that will return to Europe, and find indirect evidence that return migrants were mildly negatively selected from the migrant pool.
} 


\section{Historical background}

Many European migrants who moved to the United States in the early twentieth century eventually returned to their home country. The US government collected official statistics on both in- and out-migration from 1908 to 1923. In those years, the US received 10 million immigrant arrivals and lost 3.5 million emigrants, a return migration rate of 35 percent (Gould, 1980; Wyman, 1993 p. 10-12; Hatton and Williamson, 1998, p. 9). Return migration rates may have been even higher than the aggregate statistics suggest. Bandiera, Rasul and Viarengo (2013) find that, in order to reconcile micro data on migrant inflows to the stock of migrants remaining in the US in Census years, the return migration rate may have been as high as 70 percent. $^{6}$

Return migration rates rose as the shift from sail to steamships reduced the cost of the transatlantic voyage in the 1850s and 1860s. Travel times from Europe to the US declined from one month in 1800 to eight days by 1870 (Hugill, 1993; Cohn, 2005). Shorter trips also lowered the mortality risk of the journey (Cohn, 1984). The price of passage fell to around \$25 in 1900, which was 6 percent of mean annual earnings in the US at the time (Wyman, 1993, p. 24; Lebergott, 1964, p. 523-24). Keeling (2010) estimates that, following this transportation revolution, eastward journeys (from the US to Europe) rose from 18 percent of total transatlantic travel in the 1870 s to 30 percent by the 1900 s.

Compared to the 1920 migrant stock, return migrants were more likely to be male (80 percent versus 54 percent); less likely to be married (48 percent versus 61 percent); and more likely to come from a "new" sending country in Southern or Eastern Europe (81 percent versus 44 percent) (Ward, 2016). Return migration rates varied substantially across sending countries,

\footnotetext{
${ }^{6}$ A portion of this discrepancy could be due to repeat or circular migration.
} 
with 10 to 25 percent of Northern and Western Europeans journeying home, compared to 40 to 60 percent of Southern and Eastern Europeans (Wyman, 1993, p. 11; Gould, 1980). ${ }^{7}$

The share of migrants who returned to their country of origin in the past was, if anything, higher than the rates of return migration today. Dustmann and Gorlach (2016) show that around 20 percent of migrants to the US return home in the current period. Sociologists emphasize the "transnational" experience of contemporary migrants who "maintain various kinds of ties to their homelands," fueled by advances in communication and transportation technology (Levitt and Jaworsky, 2007, p. 129). Yet, as Foner (1997, p. 355) argues, this “transnationalism is not new,” characterizing the high rates of return and repeat migration in the early twentieth century as well.

Some return migration was planned, while other returns were unanticipated. Between 1917 and 1924, 15 percent of immigrants reported an intention to return home upon arrival in the US but 40 percent eventually did go home (Ward, 2016). In some cases, return migration was part of a deliberate strategy to move to the US temporarily, accumulate savings, and then return home to get married or purchase land. Alternatively, return migration could follow a spell of unemployment, a spate of bad health, or another idiosyncratic personal event. As one contemporary observer noted, return migrants tended to fall into two very different groups: "those who go home because they have succeeded and those who go home because they have failed” (Steiner, 1906; quoted in Wyman, 1993, p. 75). ${ }^{8}$ A small number of migrants returned

\footnotetext{
${ }^{7}$ Jewish migrants were an outlier, with return rates as low as 5 percent, although Jewish return migration was more common before the pogroms of 1903 and 1906 (Sarna, 1981).

${ }^{8}$ Consistent with this grouping, a questionnaire administered to return migrants to Finland found that 40 percent of return migrants reported having good results in the US, 19 percent reported suffering bad results, and the remainder fell somewhere in between (Wyman, 1993, p. 77).
} 
home to participate in national politics, particularly in the newly independent states that emerged out of World War I (Wyman, 1993, p. 113-118). ${ }^{9}$

A substantial body of qualitative evidence supports the idea of return migration as a means to accumulate savings. Case studies of Italians, Poles and other Central Europeans document savings of $\$ 15$ to $\$ 25$ a month in the US, or between $\$ 500$ and $\$ 900$ upon return (Wyman, 1993, p. 60, 130). Accumulating this sum would require a stay of three to five years in the US, which is consistent with one Ukranian immigrant's report that she planned to stay "just two or three years. Everybody had the same idea - make a little money and go back home” (cited in Wyman, 1993, p. 50).

Upon return, the most common investment was buying a farm, expanding an existing farm, or building a farm house. "He who crosses the ocean can buy a house" was a popular expression in Italy reflecting the value of temporary migration to the US (Cinel, 1982, p. 71). An immigration inspector in the US who interviewed repeat migrants from Italy confirmed this view, testifying that "two-thirds told me they had bought a little place in Italy, a little house and a plot of ground; that they had paid a certain sum; that there was a mortgage on it; that they were returning to this country for the purpose of making enough money to pay that mortgage off" (cited in Wyman, 1993 p. 131). A survey of 23 migrants returning to one parish in Sweden found that 16 purchased some farmland with their savings (Wyman, 1993, p. 132).

Although many successful migrants returned home in order to buy land or make other investments, others left the US after facing a period of unemployment or a debilitating illness. Wyman (1993, p. 79) notes that return migration rates were higher in years of economic downturn following the Panics of 1893 and 1907. Moreover, a notable share of return migrants

\footnotetext{
${ }^{9}$ Johan Nygaardsvold, who served as the prime minister of Norway from 1935-1945, is one such example, having migrated to Canada and the US for five years in 1902.
} 
had fallen ill in the US. 10 percent of Finnish returnees were sick or injured, and nearly 10 out of 1,000 Italians returning from the US had tuberculosis, a disease that the Irish took to calling "the American sickness” (Wyman, 1993, p. 85).

At the turn of the twentieth century, temporary migrants became a target of popular animosity, which contributed to the sentiment in favor of closing the border. Migrants who planned to return to their home country were faulted for focusing only on short-term financial gain, rather than "making serious efforts to become citizens and real Americans" (Foner, 1997, p. 367; see also Shumsky, 1992). The Dillingham Commission, which was convened by Congress in 1907 to study the effect of immigration on the US economy, adopted this view, complaining that, for temporary migrants, "acquisition of the English language will be of little consequence... The chief aim of a person with this intention is to put money in his purse” (Jenks and Lauck, 1911). In 1896, Rep. John Corliss (R-MI) proposed an amendment that "no one be admitted to the United States who still maintained a home in a foreign country” (Wyman, 1993, p. 104). Ultimately, the bill was defeated. ${ }^{10}$

\section{Data}

We develop a series of new data sets to compare Norwegian-born men who spent some time in the US ("return migrants") to Norwegian migrants still living in the US in 1910 ("permanent migrants") and to Norwegians who stayed in Norway throughout this period ("non-

${ }^{10}$ Goldin (1994) provides a detailed discussion of the politics of immigration restriction in the early twentieth century, and Abramitzky and Boustan (2016) review the economics of immigration during this period more broadly. 
movers”). When possible, we link men to earlier Norwegian Censuses taken in 1865 or 1900 to generate observations on pre-migration characteristics. ${ }^{11}$

To compare return migrants with non-movers, we start with men between the ages of 28 and 60 in the 1910 Norwegian Census; this age range allows men some time to have moved to the US temporarily and returned. The 1910 Census asked all respondents whether they had spent some time in the US and, if so, what was their date of arrival and departure, last state of residence and last occupation held. This cross section, which contains nearly 300,000 men, allows us to compare return migrants who had spent some time in the US with non-movers.

To compare return migrants with permanent migrants, we instead combine information on return migrants from the 1910 Norwegian Census with observations on Norwegian-born men still living in the US in 1910 from the 1\% US Census sample (Ruggles, et al., 2015). Some men coded here as permanent migrants may have subsequently returned to Norway after 1910, which we are unable to observe using the available historical data. ${ }^{12}$ The majority of temporary spells in the US are quite short, with more than half of return migrants spending five or fewer years in the US. Thus, to improve the accuracy of our division between permanent and return migrants, we focus on men observed in 1910 who arrived in the US before 1905, a sample of around 17,000 men.

To gather information on pre-migration characteristics, we link both of our crosssectional samples to earlier Norwegian Censuses (1865 and 1900). In particular, we link men between the ages of 28 and 45 in 1910 to the 1900 Norwegian Census (when they are between the ages of 18 and 35), creating an “early adulthood sample”. We also link men between the ages

\footnotetext{
${ }^{11}$ We are unable to link women across Censuses because women often change their last name at marriage.

12 The completed Norwegian Census is only released 100 years after the Census was taken, so the 1910 Census is the latest available to us.
} 
of 45 and 60 in 1910 to the 1865 Norwegian Census (when they are between the ages of 0 and 15), creating a “childhood sample.” These linked samples differ in two important ways. First, our early adulthood samples allow us to measure own economic outcomes before migration, while our childhood samples capture the characteristics of the household head (usually, father). Second, men in the 1900-10 linked samples moved to the US, on average, in 1903, whereas men in the 1865-1910 linked samples moved to the US in 1888. Links are conducted by first name, last name, age and country of birth (Norway). Our match rates are relatively low (10.7 percent for the 1865 to 1910 match and 23.4 percent for the 1900 to 1910 match), which is standard for this literature (Abramitzky, Boustan and Eriksson, 2012, 2014, 2016; Ferrie and Long, 2007, 2013).

Appendix Tables 1 and 2 compare men in the linked samples to the full population. As is common in historical linked datasets, men with higher socio-economic status - measured here as living in an urban area, having a father who owns land (1865) or having higher occupation-based income (1900) - are more likely to be successfully linked across Census waves. These somewhat higher match rates for men with better occupational status may be due to the fact that, in an era without birth certificates, men with some basic education were more likely to remember their age and report their name with consistent spelling. We are unfortunately unable to separately observe selection into the linked sample by migration status. ${ }^{13}$ It is encouraging that results do not change when we re-weight the sample to match the socio-economic status of the population on observed

\footnotetext{
${ }^{13}$ We measure selection into the sample using initial characteristics (either in 1865 or 1900), when the full universe of possible matches can be observed; the composition of the population may change by 1910 due to mortality. However, migration status is only revealed by observing residential location in 1910, thus making it impossible for us to separate the sample by migration status in earlier years.
} 
characteristics, but we cannot know for sure that the conclusions are not specific to our linked subset of the population.

The main economic outcome available in our historical sources is occupation. Neither the US nor the Norwegian census contains individual information on wages or income in 1910. To calculate an occupation-based earnings measure, we assign the mean (PPP-adjusted) income earned by members of their occupation based either on the US 1901 Cost of Living survey or on tabulations published by Statistics Norway for 1900 (Preston and Haines 1991; Statistik Centralbureau 1905). The online appendices for Abramitzky, Boustan and Eriksson (2012) describe these sources in more detail and explain how we calculate earnings estimates for farmers and fishermen, two occupations that are not included in the primary sources. In our analysis of economic outcomes in the US, we supplement our standard earning measure with information on the earnings of farmers and farm laborers by state from the US Census of Agriculture. Marital status and geographic location are additional outcomes of interest.

Our pre-migration characteristics are also based on occupation, either an individual's own pre-migration occupation or that of his household head. We divide own occupation observed in 1900 into deciles of occupation-based earnings. For household heads, we create six categories given the highly-concentrated occupational distribution: urban residents and, among rural residents, farmers with land, cottars with land (tenant farmers), farm laborers, fisherman, and an "other" category that includes white collar and skilled blue collar workers. These pre-migration characteristics are coarser than one might expect from the modern data. For example, Moraga (2011) uses Mexico’s Quarterly National Labor Survey, a short panel, to observe the wages of migrants before they move to the US, although, he cannot identify return migrants. 


\section{Estimating equations}

We begin our analysis by assessing the selection of return migrants from the migrant pool. Our outcome of interest is occupation-based earnings in the US. In the cross-section, we estimate:

$$
\ln (\text { OccEarnUS })_{i}{ }^{t}=\alpha+\beta \cdot D_{\text {return }}+\gamma_{1} \cdot \operatorname{age}_{i}^{1910}+\gamma_{2} \cdot\left(a g e_{i}^{1910}\right)^{2}+\epsilon_{i} \#(1)
$$

where OccEarnUS ${ }_{i}^{t}$ measures occupation-based earnings based on the last job held in the US for person $i$ observed in year $t$. ag $e_{i}^{1910}$ controls for trends in occupational attainment by birth cohort. The coefficient of interest, $\beta$, indicates whether migrants who eventually returned to Norway ( $\mathrm{D}_{\text {return }}$ ) held lower or higher paid occupations in the US, relative to migrants who stayed in the US long term.

A major concern in interpreting $\beta$ is that occupation is observed in different calendar years and, thus, at different ages for permanent and return migrants. All permanent migrants are observed in the 1910 US Census, while return migrants report their occupation in the year of their return to Norway (mean year $=1902$ ). As a result, we observe the occupations of return migrants in an earlier calendar year when the economy was less developed and earlier in the migrants' own career, both of which would tend to bias $\beta$ downward. We address this measurement issue by adding a progressive set of controls to equation 1, including: (1) age at which occupation is measured; (2) year of arrival in the US (before 1890, 1891-1900, 1901-05); (3) year in which occupation is measured (before/after 1900); and (4) age at arrival in the US. ${ }^{14}$

\footnotetext{
${ }^{14}$ Age at arrival is collinear with year of arrival and age/year in which occupation is measured. We address this multicollinearity by including two of these four variables as intervals rather than exact years.
} 
Return migrants may have had lower occupation-based earnings in the US because they arrived with less valuable skills or because they faced poor conditions in the US that prevented their ascension up the occupational ladder. To distinguish between these possibilities, we turn to measures of pre-migration occupation (or, alternatively, fathers' characteristics) in our linked samples. For example, in our early adulthood sample, which is linked between 1900 and 1910, we estimate:

$$
\ln \left({\text { OccEarnNorway })_{i}}^{1900}=\alpha+\beta^{\prime} \cdot D_{\text {return }}+\gamma_{1} \cdot \text { age }_{i}+\gamma_{2} \cdot\left(\text { age }_{i}\right)^{2}+\epsilon_{i} \#(2)\right.
$$

where OccEarnNorway ${ }_{i}^{1900}$ measures occupation-based earnings in Norway in 1900, before any move to the US takes place. $\beta$ ' indicates whether return migrants had higher or lower occupationbased earnings in Norway, before moving to the US. Comparing $\beta$ to $\beta^{\prime}$ reveals the extent to which any disadvantage faced by return migrants was present before moving to the US.

The second part of our analysis compares the occupation-based earnings of return migrants to men who stayed in Norway. We estimate the following equation for men living in Norway in 1910:

$$
\ln (\text { OccEarnNorway })_{i}{ }^{1910}=\alpha+\delta \cdot D_{\text {return }}+\gamma_{1} \cdot \text { age }_{i}+\gamma_{2} \cdot\left(a g e_{i}\right)^{2}+\epsilon_{i} \#(3)
$$

The coefficient of interest, $\delta$, estimates the earnings gap between return migrants who spent some time in the US and non-movers. In some versions of equation 3, we estimate separate earnings premia for return migrants according to time spent in the US (0-5 years, 6-10 years, 1120 years, and $21+$ years).

Time spent in the US may be valuable if migrants were able to accumulate savings to make productive investments back home or if they acquired skills at a more rapid pace than their 
counterparts who remained in Norway. Because migrants were negatively selected from the population, and return migrants especially so, we would expect $\delta$ to be negative due to initial selection. Finding a coefficient $\delta>0$ is thus suggestive that spending time in the US conferred some positive return back in the home country. Within the set of return migrants, selection on length of stay may be negative, with the most successful migrants able to accumulate savings more quickly than their less successful counterparts. We caution that estimates on the return to years spent in the US could be influenced by this form of selection, with the coefficients $\delta_{2}$ and $\delta_{3}$ then being smaller than $\delta_{1}$.

\section{Results}

\section{The selection of return migrants from the migrant pool}

One in three migrants chose to return to Europe from the US during the Age of Mass Migration. A dynamic version of the Roy model, introduced by Borjas and Bratsberg (1996), predicts positive selection of return migrants to unequal sending countries like Norway. Under this logic, Norway-to-US immigrants would be negatively selected, and the ones who return would be the ones who were just on the margin of moving to the US. Such marginal immigrants would be positively selected from the immigrant pool, because they would have more to gain from moving back to a higher-return-to-skill country. ${ }^{15}$ Instead, we find that return migrants held lower skilled occupations than permanent migrants.

Table 1 compares the earnings of return migrants and permanent migrants in the US. The first column shows that, in the raw data, return migrants earned 9 percent less than permanent

${ }^{15}$ As a result, the stock of immigrants, after the return migrants have left, would be more negatively selected than the flow of immigrants. Hence, return migration would make the stock of migrants more negatively selected, intensifying the initial selection pattern. 
migrants by our occupation-based earnings measure. However, as mentioned, all permanent migrants were observed in 1910, while the occupation of return migrants was measured in an earlier year of return. Columns 2-5 progressively control for the age and year in which occupation is measured, as well as arrival year and age at arrival in the US. After controlling for these measurement differences, our estimate suggests that return migrants earned 4 percent less than permanent migrants while in the US. In the last column, we replace our national income estimates for farmers and farm laborers with state-specific estimates. Accounting for differential geography increases the occupation-based earnings gap between return migrants and permanent migrants to 9 percent, suggesting that permanent migrants were more likely to settle in states with lucrative agricultural opportunities.

The lower occupation-based earnings of return migrants while in the US may be an indication that lower skilled migrants had a stronger incentive to return to Norway. Alternatively, migrants who eventually decided to return to Norway may have started out in a similar position to migrants who stayed in the US, but then faced a bad shock in the US, such as illness or unemployment, that encouraged them to return home. In this case, we would not expect to find differences in the pre-migration characteristics of permanent and return migrants.

Differences in pre-migration characteristics suggest that men who started out with lowerpaid occupations were more likely to return to Norway. Table 2 examines a series of premigration characteristics of men in the 1900-10 linked sample; men in this sample were observed in early adulthood in Norway in 1900. Migrants who would eventually return to Norway were 23 percentage points more likely to live in a rural area before migration. Overall, these men earned 15 percent less than permanent migrants even before moving to the US. In part, return migrants 
were at an occupation-based earnings disadvantage because they were more likely to live in rural areas; however, return migrants also earned less within rural and within urban areas.

A similar pattern emerges in Table 3, which compares the characteristics of fathers whose sons would eventually move to the US permanently or on a temporary basis. Again, the fathers of return migrants were 27 percentage points more likely to live in a rural area. Within rural areas, the fathers of return migrants were more likely to be owner-occupier farmers, a relatively highly paid profession (16 percentage points). Yet this gap was mostly offset by a lower probability of being in the "other" category as a white collar or blue collar worker (9 percentage points). Note also that, within this broad "other" category, the fathers of return migrants earned 17 percent less than the fathers of permanent migrants.

We then assess the extent to which differences in pre-migration characteristics can account for the earning gap between return and permanent migrants in the US. If an earnings gap remains even after controlling for pre-migration differences, this residual may point to a role of negative shocks as an impetus for return migration. Table 4 starts by re-estimating the earning difference between return and permanent migrants in our linked samples. Column 3 then adds pre-migration characteristics, including a dummy for living in a rural area, and indicators for decile in the occupation-based earnings distribution (in 1900) or indicators for fathers' status (in 1865). Controlling for own occupation in 1900 completely eliminates the earnings gap between return and permanent migrants. However, despite the differences in fathers' background by migration status (Table 3), controlling for fathers' occupation does not change the estimated earnings gap. ${ }^{16}$ In this era of rural-to-urban transition within Norway, fathers' background does

${ }^{16}$ One difference between the own occupation and father controls is the degree of available detail. We tried coarsening the own occupation controls, using the same set of categories 
not appear to be a good predictor of sons’ potential occupation. In this context, own occupation offers a better measure of initial selection.

Controlling for pre-migration occupation reveals that differences by migration status were apparent even before moving to the US, and thus are not likely due to barriers or shocks faced in the US. Rather, men with lower skills seem to have had the strongest economic incentive to return to Norway. At the time, Norway was more unequal than the US and so a Roy model would predict that the migrant just on the margin between staying the US and returning to Norway would be relatively high skilled. Return migration of the low skilled is instead more consistent with the idea of temporary migration to alleviate borrowing constraints at home. Norway was not very financially developed at the beginning of the mass migration; in this setting, the lower skilled were likely to face borrowing constraints. ${ }^{17}$ By moving to the US, migrants could expect a 70 percent increase in earnings, or an additional \$10 a month for a farm laborer who earned around \$175 per year in 1900 dollars (Abramitzky, Boustan and Eriksson, 2012). According to the qualitative evidence described in section II, saving this excess return would be sufficient to buy a plot of land within a three to five year stay in the US.

\section{The value of time spent in the US}

Spending some time in the US offered migrants the opportunity to save up for productive investments back in Norway. These savings may have allowed return migrants to ascend the

available for fathers' background; yet, these coarse controls still eliminate the earnings gap in the 1900-10 matched sample.

17 The Norwegian banking sector was small in 1860, with only 47 kroner of assets in commercial and savings banks per capita (Nordvik, 1993). At the time, GDP per capita was around 250 kroner, implying a ratio of financial assets to GDP of 0.2 (Grytten, 2008). For comparison, the mean ratio of assets of financial institutions to GDP was nearly 0.9 for industrialized countries in 1900 (Rousseau and Wachtel, 1998). Bank capital grew quickly in Norway over the next forty years, expanding five times faster than GDP. 
occupational ladder and out-earn men who never moved to the US, even given the initial negative selection of this migrant group. Table 5 begins by analyzing the full cross-section of men between the ages of 28 and 60 who lived in Norway in 1910. Men who spent some time in the US earned 4 percent more in our occupation-based earnings measure than did men who never moved (column 1). Column 2 shows that the value of time spent in the US was higher for men who worked in a non-agricultural occupation while abroad, likely in an urban area (5 percent), relative to men who worked in farming (1 percent). In the late nineteenth century, the urban wage premium was 30-40 percent in the US (Boustan, Bunten and Hearey, 2013); higher pay in urban areas would have allowed return migrants to accumulate savings more quickly. Given that many return migrants worked in agriculture upon return (as we describe below), this pattern is not consistent with the idea of acquiring transferrable skills in the destination country, but more so with acquiring savings to invest at home.

The value of time spent in the US diminished over the nineteenth century. According to column 3, migrants who moved to the US before 1890 earned 8 percent more than non-migrants of the same age; the earnings premium fell to 5 percent for men who moved in the 1890s and to zero for men who moved in the 1900s. This pattern could arise if migrant selection was less negative at the beginning of the mass migration or, alternatively, if the relative ability to accumulate savings in the US was highest when the wage gap between the two countries was maximized, before Norway began to converge with the US.

Among return migrants, the largest earnings premium was earned by men who spent less than five years in the US, with additional time in the US diminishing the migrant earnings advantage. Column 4 adds indicators for time spent in the US, with 1-5 years as the omitted category. Men who moved before 1900 and stayed in the US for less than five years earned a 
premium of 7-11 percent relative to non-migrants. Men who instead stayed for 6-10 years had a 2 percentage point reduction in their earnings premium; men who stayed for 11-20 years had a 4 percentage point reduction, and so on.

That the peak migration premium occurred after just five years in the US stands in contrast to contemporary data from Mexico, in which each year spent in the US confers an economic return of 2.2 percent of monthly earnings (Reinhold and Thom, 2013). In the modern period, migrants may be acquiring valuable work experience in more advanced destination economies that is then transferrable to the home country. In our historical period, we suspect that migrants were accumulating savings rather than skills, and that the more successful were able to amass the necessary sums more quickly. Thus, what appears to be a falling return to additional time spent in the US may be picking up negative selection on length of stay.

Our estimates for the value of time spent in the US are likely biased downward by the fact that migrants were negatively selected from the sending population, and return migrants especially so. Table 6 partially corrects for this selection by controlling for pre-migration occupation in the sample linked between 1900 and 1910. Note that all migrants in this sample left for the US after 1900; according to Table 5, migrants in this arrival cohort on average earned 2 percent less than non-movers. Column 2 replicates this pattern for the linked sample, documenting that the 2 percent earnings penalty is a weighted average of no occupation-based earnings loss for return migrants with short stays in the US (1-3 years) and a 4 percent occupation-based earnings penalty for return migrants with longer stays (4-9 years). Column 3 adds controls for pre-migration occupation in Norway in 1900. The earnings premium for return migrants is shifted up by 3 percentage points for both migrant types. After controlling for pre- 
migration characteristics, short-term return migrants appear to have earned 3 percent more than non-movers, while return migrants with longer stays earned only slightly less than non-movers.

Comparing estimates with and without pre-migration controls suggests that return migrants were negatively selected relative to the population, biasing downward our initial estimates of the value of time spent in the US. Indeed, if the observed shift in the coefficients in the 1900-10 linked sample applied to the full population estimate, spending time in the US might have increased earnings by 7 percent (rather than 4 percent). However, migrants with longer stays in the US do not seem to have been differentially selected, at least not on the set of premigration characteristics that we are able to observe. Rather, adding pre-migration controls shifts up the estimated value of time spent in the US for short- and long-term stays to the same degree.

Spending some time in the US helped return migrants climb the occupational ladder in Norway. Yet, additional time in the US (beyond five years) did not confer any added value and, if anything, diminished the earnings premium associated with being a return migrant. To further understand this pattern, we turn to a descriptive analysis of the occupations and residential locations of return migrants. Table 7 documents that return migrants were substantially more likely than the rest of the population to live in a rural area (17-20 percentage points) and to work as an owner-occupier farmer (14-25 percentage points), often in the migrant's own municipality of birth. These differences remain sizeable even after controlling for initial location (rural/urban) and own or father's occupation before migration. The occupational and geographic choices of return migrants are consistent with the qualitative evidence, which suggests that temporary moves to the US were used as a means of accumulating saving in order to buy land at home.

Men who were working as farm laborers in early adulthood may have been particularly likely to face borrowing constraints and keen to acquire land. Table 8 focuses on men in the 
1900-10 linked sample who were farm laborers in 1900, reporting the ten most common occupations in Norway in 1910 by migration status. Men who spent some time in the US were 9 percentage points more likely to be owner-occupier farmers, with the difference primarily made up by non-movers holding a broader array of occupations outside of the top ten. Half of men who did not move to the US left their municipality of birth, often moving to an urban area within Norway, in which the set of potential occupations was much wider. We also compare return migrants to men who stayed in their birth municipality. In this case, return migrants were equally likely to be an owner-occupier farmer (40 percent) but were 12 percentage points less likely to be further down the agricultural ladder as a farm laborer or cottar (tenant farmer).

Moving to the US was one way for lower skilled Norwegian men to get ahead, with a temporary stay in the US allowing some farm laborers to save up and buy land at home. However, overseas migration was not the only approach: other men who started out on the lower rungs of the occupational ladder left their municipality of birth to move to urban areas within Norway. These men were less likely to be owner occupier farmers circa age 35, but instead held a broader array of urban occupations.

Beyond acquiring land, another motivation for temporary migration was saving up money to afford a marriage. In Norway, as in much of Northern and Western Europe, age at marriage was determined in part by the ability to set up a separate household, which often required a period of savings, often as a servant in another family's household (Hajnal, 1965; Kussmaul, 1981; Guinnane, 1991). An alternative to saving at home would have been engaging in a temporary move to the US. In this case, we expect return migrants to have lower marriage rates before their move (in 1900) but higher marriage rates after return (in 1910). Table 9 finds precisely this pattern: men who spent some time in the US were 3 percentage points less likely to 
be married before moving but 3 percentage points more likely to be married after return. This pattern is consistent with the idea of temporary migration as a means to save for marriage.

\section{Conclusions}

We study return migration from US to Norway during the Age of Mass Migration. We take advantage of a question in the 1910 Norwegian Census asking all residents whether they had spent time in the US and when they returned. We construct large cross-sectional and panel datasets that allow us to compare return migrants to permanent migrants still living in the US and non-migrants who never left Norway.

Return migrants were negatively selected relative to immigrants who stayed in the US. Not only did Norwegian immigrants who returned to Norway hold lower-paid occupations while in the US, but they also held lower-paid occupations even before their move. This finding suggests that negative selection was unlikely due to barriers or bad shocks faced in the US. Rather, men with lower skills seem to have had the strongest economic incentive to return to Norway.

Upon returning to Norway, return migrants held higher-paid occupations than Norwegians who never moved, despite hailing from poorer backgrounds. Despite being negatively selected, return migrants were able to accumulate savings and improve their economic circumstances once they returned home. These savings were used to acquire land in order to work as an owner-occupier farmer and to afford the costs associated with setting up an independent household before marriage.

Moving to the New World was one strategy that poor European immigrants used to achieve economic success. This paper suggests that temporary movement to the US in order to accumulate savings and invest in the home country was another option available to poor 
Europeans. Perhaps as result, one in three European migrants returned home during this period. 


\section{References}

Abramitzky, Ran, and Leah Platt Boustan. "Immigration in American Economic History." NBER Working Paper No. 21882 (2016).

Abramitzky, Ran, Leah Platt Boustan, and Katherine Eriksson. "Europe’s Tired, Poor, Huddled Masses: Self-selection and Economic Outcomes in the Age of Mass Migration.” American Economic Review 102, no. 5 (2012): 1832-1856.

Abramitzky, Ran, Leah Platt Boustan, and Katherine Eriksson. "Have the Poor Always Been Less Likely to Migrate? Evidence from Inheritance Practices during the Age of Mass Migration.” Journal of Development Economics, no. 102 (2013): 2-14.

Abramitzky, Ran, Leah Platt Boustan, and Katherine Eriksson. "A Nation of Immigrants: Assimilation and Economic Outcomes in the Age of Mass Migration.” Journal of Political Economy 122, no. 3 (2014): 467-506.

Abramitzky, Ran, Leah Platt Boustan, and Katherine Eriksson. "Cultural Assimilation during the Age of Mass Migration,” NBER Working Paper No. 22381(2016).

Aydemir, Abdurrahman, and Chris Robinson. "Global Labour Markets, Return, and Onward Migration.” Canadian Journal of Economics 41, no. 4 (2008): 1285-1311.

Bandiera, Oriana, Imran Rasul, and Martina Viarengo. "The Making of Modern America: Migratory Flows in the Age of Mass Migration.” Journal of Development Economics 102 (2013): 23-47.

Bijwaard, Govert E., Christian Schluter, and Jackline Wahba. "The Impact of Labor Market Dynamics on the Return Migration of Immigrants." Review of Economics and Statistics 96, no. 3 (2014): 483-494.

Borjas, G. J., and B. Bratsberg. "Who Leaves? The Outmigration of the Foreign-born.” Review of Economics and Statistics 78, no. 1 (1996): 165-76.

Boustan, Leah Platt, Devin Bunten, and Owen Hearey. "Urbanization in the United States, 18002000.” NBER Working Paper w19041, May 2013.

Centralbureau, Statistiske. "Statistik Aarbog for Kongeriget Norge (Annuaire Statistique de la Norvege).” Kristiania, Norway: I Kommission Hos H. Aschehough \& Co (1905).

Cinel, Dino. From Italy to San Francisco: The Immigrant Experience. Palo Alto: Stanford University Press, 1982. 
Cohn, Raymond L. "Mortality on Immigrant Voyages to New York, 1836-1853." Journal of Economic History 44, no. 2 (1984): 289-300.

Cohn, Raymond L. "The Transition from Sail to Steam in Immigration to the United States." Journal of Economic History 65, no. 02 (2005): 469-495.

Dustmann, Christian, and Joseph-Simon Görlach. "The Economics of Temporary Migrations.” Journal of Economic Literature 54, no. 1 (2016): 98-136.

Foner, Nancy. "What's New about Transnationalism?: New York Immigrants Today and At the Turn of the Century.” Diaspora: A Journal of Transnational Studies 6, no. 3 (1997): 355375.

Goldin, Claudia. "The Political Economy of Immigration Restriction in the United States, 1890 to 1921." In Claudia Goldin and Gary Libecap, eds. The Regulated Economy: A Historical Approach to Political Economy, pp. 223-258. Chicago: University of Chicago Press, 1994.

Gould, John D. "European Inter-continental Emigration. The Road Home: Return Migration from the USA.” Journal of European Economic History 9, no. 1 (1980): 41.

Grytten, Ola. "The Economic History of Norway”. EH.Net Encyclopedia, edited by Robert Whaples. March 16, 2008. URL http://eh.net/encyclopedia/the-economic-history-ofnorway/

Guinnane, Timothy. "Re-thinking the Western European Marriage Pattern: The Decision to Marry in Ireland at the Turn of the Twentieth Century.” Journal of Family History 16, no. 1 (1991): 47-64.

Hatton, Timothy J., and Jeffrey G. Williamson. The Age of Mass Migration: Causes and Economic Impact. New York: Oxford University Press, 1998.

Haines, Michael, and Samuel Preston. "Fatal Years: Child Mortality in Late Nineteenth America." Princeton, NJ: Princeton University Press, 1991.

Hajnal, John. "European Marriage Patterns in Perspective. In D.V. Glass and D.E.C. Eversley, eds. Population in History: Essays in Historical Demography. New Brunswick, NJ: Transaction Publishers, 1965, 101-43.

Hugill, Peter J. World Trade since 1431: Geography, Technology, and Capitalism. Baltimore: Johns Hopkins University Press, 1993.

Jenks, Jeremiah Whipple, and William Jett Lauck. The Immigration Problem. Funk \& Wagnalls Company, 1911. 
Keeling, Drew. "Repeat Migration between Europe and the United States, 1870-1914.” In Laura Cruz and Joel Mokyr, eds. The Birth of Modern Europe: Culture and Economy, 1400 to 1800: Essays in Honor of Jan de Vries. Leiden: Brill, 2010, p. 157-186

Kussmaul, Ann. Servants in Husbandry in Early Modern England. New York: Cambridge University Press, 1981.

Lebergott, Stanley. Manpower in Economic Growth: The American Record since 1800. New York: McGraw-Hill, 1964.

Levitt, Peggy, and B. Nadya Jaworsky. "Transnational Migration Studies: Past Developments and Future Trends.” Annual Review of Sociology, 33 (2007): 129-156.

Long, Jason, and Joseph Ferrie. "The Path to Convergence: Intergenerational Occupational Mobility in Britain and the US in Three Eras.” Economic Journal 117, no. 519 (2007): C61-C71.

Long, Jason, and Joseph Ferrie. "Intergenerational Occupational Mobility in Great Britain and the United States since 1850.” American Economic Review 103, no. 4 (2013): 1109-1137.

Mesnard, Alice. “Temporary Migration and Capital Market Imperfections.” Oxford Economic Papers 56, no. 2 (2004): 242-262.

Moraga, Jesus Fernandez-Huertas. "New Evidence on Emigrant Selection." Review of Economics and Statistics 93, no. 1 (2011): 72-96.

Nordvik, Helge W. "The Banking System, Industrialization and Economic Growth in Norway, 1850-1914.” Scandinavian Economic History Review 41, no. 1 (1993): 51-72.

Reinhold, Steffen, and Kevin Thom. "Migration Experience and Earnings in the Mexican Labor Market.” Journal of Human Resources 48, no. 3 (2013): 768-820.

Rooth, Dan-Olof, and Jan Saarela. "Selection in Migration and Return Migration: Evidence from Micro Data.” Economics Letters 94, no. 1 (2007): 90-95.

Rousseau, Peter L., and Paul Wachtel. "Financial Intermediation and Economic Performance: Historical Evidence from Five Industrialized Countries." Journal of Money, Credit and Banking 30, no. 4 (1998): 657-678.

Ruggles, Steven, Katie Genadek, Ronald Goeken, Josiah Grover, and Matthew Sobek. Integrated Public Use Microdata Series: Version 6.0 [Machine-readable database]. Minneapolis: University of Minnesota, 2015.

Sarna, Jonathan D. "The Myth of No Return: Jewish Return Migration to Eastern Europe, 18811914.” American Jewish History 71, no. 2 (1981): 256-268. 
Shumsky, Neil Larry. “'Let No Man Stop to Plunder!’ American Hostility to Return Migration, 1890-1924.” Journal of American Ethnic History 11, no. 2 (1992): 56-75.

Steiner, Edward Alfred. On the Trail of the Immigrant. New York: FH Revell Company, 1906.

Wahba, Jackline, and Yves Zenou. "Out of Sight, Out of Mind: Migration, Entrepreneurship and Social Capital.” Regional Science and Urban Economics 42, no. 5 (2012): 890-903.

Ward, Zachary. "Birds of Passage: Return Migrants, Self-Selection and Immigration Quotas." Manuscript 2016.

Wyman, Mark. 1993. Round-trip to America: The Immigrants Return to Europe, 1880-1930. Ithaca, N.Y.: Cornell University Press.

Yang, Dean. "Why Do Migrants Return to Poor Countries? Evidence from Philippine Migrants' Responses to Exchange Rate Shocks." Review of Economics and Statistics 88, no. 4 (2006): 715-735. 
Table 1: Occupation-based earnings in the US, Return vs. permanent migrants in cross-section

Dependent variable $=\ln ($ occupation-based income in US)

\begin{tabular}{l|cccccc}
\hline & $(1)$ & $(2)$ & $(3)$ & $(4)$ & $(5)$ & $(6)$ \\
\hline$=1$ if return & -0.088 & -0.048 & -0.052 & -0.035 & -0.034 & -0.089 \\
& $(0.010)$ & $(0.016)$ & $(0.016)$ & $(0.016)$ & $(0.016)$ & $(0.018)$ \\
Age at occup & & & & & & \\
Arrive cohort & $\mathrm{N}$ & $\mathrm{Y}$ & $\mathrm{Y}$ & $\mathrm{Y}$ & $\mathrm{Y}$ & $\mathrm{Y}$ \\
Year at occup & $\mathrm{N}$ & $\mathrm{N}$ & $\mathrm{Y}$ & $\mathrm{Y}$ & $\mathrm{Y}$ & $\mathrm{Y}$ \\
Arrive age & $\mathrm{N}$ & $\mathrm{N}$ & $\mathrm{N}$ & $\mathrm{Y}$ & $\mathrm{Y}$ & $\mathrm{Y}$ \\
State farm income & $\mathrm{N}$ & $\mathrm{N}$ & $\mathrm{N}$ & $\mathrm{N}$ & $\mathrm{Y}$ & $\mathrm{Y}$ \\
\hline
\end{tabular}

Notes: $N=17,157$. Sample $=$ Norwegian-born men between the ages of 28 and 60 in 1910 who migrated to the US before 1905. Return = 1 if observed in Norwegian Census of 1910 and report having spent some time in US. Return = 0 if observed in US Census of 1910 (1\% IPUMS sample). Column 2 controls for quadratic in age at time of occupation measurement. Column 3 adds indicators for three arrival cohorts (before 1890, 1891-1900, 1901-10). Column 4 adds indicator for occupation observed before 1900. Column 5 adds indicator for arriving the US before the age of 16 . Column 6 replaces the national income estimate for farmers and farm laborers with state-specific measures. 
Table 2: Pre-migration characteristics in Norway in 1900:

Return vs. permanent migrants in linked sample

\begin{tabular}{l|c}
\multicolumn{2}{c}{ Coefficient on $=1$ if return to US } \\
\hline Dependent variables & -0.233 \\
\hline 1 if urban & $(0.019)$ \\
$N=3008$ & -0.154 \\
$\ln ($ earnings), all & $(0.020)$ \\
$N=2451$ & -0.091 \\
$\ln ($ earnings), if rural & $(0.021)$ \\
$N=1651$ & -0.069 \\
$\ln ($ earnings), if urban & $(0.046)$ \\
$N=800$ & \\
\hline
\end{tabular}

Notes: Sample includes men between the ages of 18 and 35 living in Norway in 1900 who can be linked to the 1910 US or Norwegian Census. Analysis limited to men who migrated to the US before 1905. All regressions control for a quadratic for age in 1900. See Appendix Table 2 for means of the dependent variables. 
Table 3: Fathers' characteristics in Norway in 1865:

Return vs. permanent migrants in linked sample

\begin{tabular}{|c|c|c|c|}
\hline Category: & $\begin{array}{c}\text { Permanent } \\
\text { Migrants }\end{array}$ & $\begin{array}{c}\text { Return } \\
\text { Migrants }\end{array}$ & $\begin{array}{c}\text { Non } \\
\text { migrants }\end{array}$ \\
\hline Share urban & $\begin{array}{l}35.6 \% \\
(\$ 397)\end{array}$ & $\begin{array}{l}8.9 \% \\
(\$ 419)\end{array}$ & $\begin{array}{l}12.6 \% \\
(\$ 388)\end{array}$ \\
\hline $\begin{array}{l}\text { For rural fathers: } \\
\text { Farmers with Land } \\
\text { Mean income }=\$ 390\end{array}$ & $39.0 \%$ & $54.7 \%$ & $44.0 \%$ \\
\hline $\begin{array}{l}\text { Farm laborers } \\
\text { Mean income }=\$ 338\end{array}$ & $12.9 \%$ & $8.7 \%$ & $11.9 \%$ \\
\hline $\begin{array}{l}\text { Fishermen } \\
\text { Mean income }=\$ 263\end{array}$ & $3.4 \%$ & $3.0 \%$ & $4.2 \%$ \\
\hline $\begin{array}{l}\text { Cottars with Land } \\
\text { Mean income }=\$ 125\end{array}$ & $19.5 \%$ & $17.7 \%$ & $20.7 \%$ \\
\hline $\begin{array}{l}\text { Other } \\
\text { Mean income }\end{array}$ & $\begin{array}{l}25.2 \% \\
(\$ 427)\end{array}$ & $\begin{array}{l}16.0 \% \\
(\$ 365)\end{array}$ & $\begin{array}{l}19.0 \% \\
(\$ 353)\end{array}$ \\
\hline Total rural: & $100 \%$ & $100 \%$ & $100 \%$ \\
\hline $\mathrm{N}$ & 1,946 & 528 & 21,508 \\
\hline
\end{tabular}

Notes: Sample includes men between the ages of 3 and 15 living in Norway in 1865 who can be linked to the 1910 US or Norwegian Census. Columns 1 and 2 are limited to men who migrated to the US before 1905. Father characteristics combine information on occupation and landholdings from the "hierarchy" variable in the 1865 Norwegian Census. 
Table 4: Occupation-based earnings in US, Permanent vs. return migrants, controlling for pre-migration occupations

Dependent variable $=\ln ($ occupation-based income in US)

\begin{tabular}{l|ccc}
\hline & $\begin{array}{c}(1) \\
\text { No controls }\end{array}$ & $\begin{array}{c}(2) \\
\text { Control age and year } \\
\text { of occup. measure }\end{array}$ & $\begin{array}{c}(3) \\
\text { Add pre-mig } \\
\text { characteristics }\end{array}$ \\
\hline \multirow{3}{*}{$=1$ if return } & -0.083 & $1900-10$ sample \\
& $(0.016)$ & -0.053 & -0.010 \\
& & $(0.019)$ & $(0.021)$ \\
& & & \\
& -0.219 & $1865-1910$ sample & -0.096 \\
& $(0.017)$ & -0.097 & $(0.030)$ \\
\hline
\end{tabular}

Notes: $N=2,819$ (row 1) and $N=3,273$ (row 2). Samples include men between the ages of 18 and 35 (row 1) or 3 and 15 (row 2) living in Norway in 1900 (row 1) or 1865 (row 2) who can be linked to the 1910 US or Norwegian Census. The analysis is further restricted to migrants who arrived in US before 1905. Column 2 controls for a quadratic in age at which occupation is measured and an indicator for whether occupation is measured before 1906 (row 1) or before 1900 (row 2). Because the 1865-1910 linked sample contains a large set of arrival cohorts, we also control for three indicators for arrival cohort in row 2 (before 1890, 1891-1900, 1901-1910). Column 3 includes measures of pre-migration characteristics, including deciles in the occupation-based earnings distribution in 1900 (row 1) or indicators of father's urban and occupational status (row 2). 
Table 5: Value of time spent in US, Return migrants vs. non-movers in Norway in 1910

\begin{tabular}{|c|c|c|c|c|}
\hline & $(1)$ & $(2)$ & (3) & (4) \\
\hline$=1$ if ever in US & $\begin{array}{c}0.036 \\
(0.004)\end{array}$ & & & \\
\hline$=1$ if in US, farm & & $\begin{array}{c}0.009 \\
(0.007)\end{array}$ & & \\
\hline$=1$ if in US, non-farm & & $\begin{array}{c}0.048 \\
(0.005)\end{array}$ & & \\
\hline Moved before 1890 & & & $\begin{array}{c}0.079 \\
(0.007)\end{array}$ & $\begin{array}{c}0.106 \\
(0.009)\end{array}$ \\
\hline Moved 1891-1900 & & & $\begin{array}{c}0.049 \\
(0.006)\end{array}$ & $\begin{array}{c}0.068 \\
(0.008)\end{array}$ \\
\hline Moved 1901-1910 & & & $\begin{array}{c}-0.016 \\
(0.007)\end{array}$ & $\begin{array}{c}-0.011 \\
(0.007)\end{array}$ \\
\hline In US, 6-10 yrs & & & & $\begin{array}{c}-0.022 \\
(0.010)\end{array}$ \\
\hline In US, $11-20$ yrs & & & & $\begin{array}{c}-0.043 \\
(0.012)\end{array}$ \\
\hline In US, $21+$ yrs & & & & $\begin{array}{r}-0.065 \\
(0.019) \\
\end{array}$ \\
\hline
\end{tabular}

Notes: $N=296,914$. Sample includes men between the ages of 28 and 60 in the 1910 Norwegian Census. Ever in the US $=1$ if men report having spent some time in the US and have since returned to Norway. Farm status in the US measured from reported occupation. Years spent in the US measured from reported year of arrival and departure. All regressions control for a quadratic in age in 1910. 
Table 6: Occupation-based earnings in Norway 1910, Return migrants vs. non-movers, controlling for pre-migration occupations

Dependent variable $=\ln$ (occupation-based income in Norway, 1910)

\begin{tabular}{l|ccc}
\hline & $(1)$ & $(2)$ & $(3)$ \\
& Cross-section & $1900-10$ match & Match + controls \\
\hline In US 3 years or less & 0.009 & 0.002 & 0.029 \\
& $(0.010)$ & $(0.015)$ & $(0.015)$ \\
In US more than 3 years & -0.034 & -0.043 & -0.015 \\
& $(0.010)$ & $(0.015)$ & $(0.016)$ \\
$N$ & 178,684 & 55,804 & 55,804 \\
\hline
\end{tabular}

Note: Samples include men between the ages of 28 and 45 living in Norway in 1910. Column 1 contains all men in the cross section of the Norwegian Census. Columns 2 and 3 include only those men that can be linked between 1900 and 1910. Column 3 controls for pre-migration characteristics by decile in the occupation-based earnings distribution in 1900. All regressions control for a quadratic in age in 1910. 
Table 7: Occupation and geographic location in Norway 1910, Return migrants vs. non-movers

\begin{tabular}{|c|c|c|c|c|c|}
\hline & \multicolumn{2}{|c|}{$=1$ if urban } & \multicolumn{2}{|c|}{$=1$ if farmer } & $\begin{array}{c}=1 \text { if birth } \\
\text { municipality }\end{array}$ \\
\hline$=1$ if ever in US & $\begin{array}{c}-0.172 \\
(0.010)\end{array}$ & $\begin{array}{c}-0.135 \\
(0.009)\end{array}$ & $\begin{array}{c}-1910 \mathrm{sar} \\
0.138 \\
(0.013)\end{array}$ & $\begin{array}{c}0.126 \\
(0.010)\end{array}$ & $\begin{array}{c}0.149 \\
(0.012)\end{array}$ \\
\hline$=1$ if ever in US & $\begin{array}{l}-0.204 \\
(0.014)\end{array}$ & $\begin{array}{c}-0.191 \\
(0.015)\end{array}$ & $\begin{array}{c}-1910 \text { sar } \\
0.256 \\
(0.024)\end{array}$ & $\begin{array}{c}0.244 \\
(0.024)\end{array}$ & $\begin{array}{c}0.140 \\
(0.024)\end{array}$ \\
\hline Pre-mig control? & $\mathrm{N}$ & $\mathrm{Y}$ & $\mathrm{N}$ & $\mathrm{Y}$ & $\mathrm{N}$ \\
\hline
\end{tabular}

Note: $N=69,350$ (row 1) and $N=15,017$ (row 2). Samples include men between the ages of 18 and 35 (row 1) or 3 and 15 (row 2) living in Norway in 1900 (row 1) or 1865 (row 2) who can be linked to the 1910 US or Norwegian Census. All regressions control for a quadratic in age in 1910. Columns 2 and 4 also control for a lagged version of the dependent variable (urban or farmer status in 1865 or 1900). 
Table 8: Top ten occupations held in 1910 by men who were farm laborers in 1900, Return migrants vs. non-movers

\begin{tabular}{lclclc}
\hline \multicolumn{2}{c}{$=1$ if ever US } & \multicolumn{2}{c}{$=0$ if ever US } & \multicolumn{2}{c}{ if US, in birth munic. } \\
\hline Farmer & 40.0 & Farmer & 30.8 & Farmer & 39.7 \\
Farm worker & 15.6 & Farm worker & 17.0 & Farm worker & 25.4 \\
Fishermen & 5.2 & Farm \& fish & 4.5 & Farm \& fish & 4.4 \\
No occup. & 4.8 & Fishermen & 4.4 & No occup. & 3.4 \\
Carpenters & 4.0 & No occup. & 2.9 & Cottar & 3.0 \\
Lumbermen & 3.6 & Lumbermen & 2.9 & Lumbermen & 2.9 \\
Farm \& fish & 3.2 & Cottar & 2.5 & Fishermen & 2.8 \\
Railway & 2.8 & Carpenter & 2.4 & Carpenter & 2.0 \\
Day laborer & 2.8 & Day laborer & 1.8 & Day laborer & 1.4 \\
Cottar & 1.6 & Paper mill & 1.3 & Servant & 1.3 \\
& & & & & \\
Total & 83.6 & Total & 69.2 & Total & 86.2 \\
$N$ & 250 & $N$ & 7872 & $N$ & 4006 \\
\hline
\end{tabular}

Notes: Sample include men between the ages of 18 and 35 living in Norway in 1900 who can be linked to the 1910 Norwegian Census. The analysis is limited to men who report being farm laborers in 1900. 
Table 9: Marital status in 1900 and 1910, Return migrants vs. non-movers

\begin{tabular}{l|cc}
\hline & Married, 1900 & Married, 1910 \\
\hline =1 if ever in US & -0.031 & 0.032 \\
& $(0.014)$ & $(0.019)$ \\
Control 1900 & $\mathrm{N}$ & $\mathrm{N}$ \\
\hline
\end{tabular}

Notes: $N=2$ 2,857. Sample include men between the ages of 18 and 35 living in Norway in 1900 who can be linked to the 1910 Norwegian Census. Regressions control for a quadratic in age. Column 3 also includes a control for marital status in 1900. 
Appendix Table 1: Comparing the Linked Sample to the Population, 1865

\begin{tabular}{l|cc}
\hline & Population & $\begin{array}{c}\text { Difference: } \\
\text { Linked - Population }\end{array}$ \\
\hline Age & 8.682 & $0.208^{* * *}$ \\
& $(3.708)$ & $(0.029)$ \\
& & $0.078^{* * *}$ \\
For urban & 0.144 & $(0.003)$ \\
Farmers with Land & $(0.351)$ & \\
& & $0.014^{* * *}$ \\
Farm laborers & 0.413 & $(0.005)$ \\
& $(0.492)$ & -0.003 \\
Fishermen & 0.138 & $(0.003)$ \\
& $(0.345)$ & $0.003^{*}$ \\
Cottars with Land & 0.036 & $(0.002)$ \\
& $(0.186)$ & $-0.032^{* * *}$ \\
Other & 0.238 & $(0.004)$ \\
& $(0.425)$ & $0.017^{* * *}$ \\
\hline
\end{tabular}

Notes: $N=266,787, N=226,983$ for rural sample. Sample includes men between the ages of 3 and 15 in the 1865 Norwegian Census. First column presents means and standard deviations of the population. The last column presents the coefficient and standard error on an indicator for being in the linked sample from a regression of the outcome of interest on linked status. 
Appendix Table 2: Comparing the Linked Sample to the Population, 1900

\begin{tabular}{l|cc}
\hline & Population & $\begin{array}{c}\text { Difference: } \\
\text { Linked - Population }\end{array}$ \\
\hline Age & 25.45 & $0.555^{* * *}$ \\
1 if urban & $(5.137)$ & $(0.021)$ \\
& 0.321 & $0.011^{* * *}$ \\
$=1$ if head of household & $(0.466)$ & $(0.001)$ \\
& 0.306 & $0.070^{* * *}$ \\
$\ln$ (occupation-based income) & $(0.461)$ & $(0.002)$ \\
& 5.638 & $0.038^{* * *}$ \\
& $(0.437)$ & $(0.002)$ \\
\hline
\end{tabular}

Notes: $\mathrm{N}=376,507$. Sample includes men between the ages of 18 and 35 in the 1900 Norwegian Census. First column presents means and standard deviations of the population. The last column presents the coefficient and standard error on an indicator for being in the linked sample from a regression of the outcome of interest on linked status. 